\title{
THE POPE COLLECTION OF ALCHEMICAL PAINTINGS AND ENGRAVINGS
}

\author{
By Prof. John Read, F.R.S.
}

$\mathrm{T}^{\mathrm{H}}$ HE late Sir William Jackson Pope, professor of chemistry in the University of Cambridge from 1908 until 1939 , besides being one of the most eminent of British chemists, was known among the cognoscenti as a discerning collector of alchemical paintings and engravings. His treasures included many fine examples, either originals or engravings, of the work of the younger Teniers, Wijck, Bega, Steen, and other painters of the celebrated Dutch school of the seventeenth century. Among other items of much interest there was an unusually complete series of the rich reproductions in mezzo-tint of the paintings of Joseph Wright, the eighteenth-century painter of Derby, whose strangely effective high-lights are seen to such advantage in his representation of the discovery of phosphorus and in his charming study of a philosopher giving a lecture on the orrery.

There was also an impression of the rare engraving on copper, dated 1643, showing the experimenting Franciscan monk, Bertold Schwartz ("Black Bertold"), of Freiburg im Breisgau, "Doctor, Alchimist, und Erfinder der freijen Kunst des Büchsenschiessens, im Jar 1380", firing a charge of gunpowder with a flint and steel in his laboratory. Very exceptionally, the collection contained engravings in both 'enantiomorphous forms' of 'Teniers' "Le Plaisir des Fous": this famous picture, caricaturing the unintelligent operations of the 'puffers', or exoteric alchemists, depicts an ape seated at an alchemist's hearth with a pair of bellows, the operative paw being the right in one reproduction and the left in its 'mirror-image'. The pair of small engravings, which used to face each other upon the mantelpiece of Pope's study in Cambridge, naturally made a strong appeal to the great master of stereochemistry, who had taken delight for so long in the production of new and startling dextro- and lævo-forms in the laboratory.

One of the most attractive items in the collection was an original oil-painting, "The Chemyst", by Cornelis Pietersz Bega. This used to grace the entrance hall of the owner's Cambridge home, and it came from the Sawbridge-Earle-Drax Collection. Painted on. a wooden panel, it is remarkable for the purity of its flesh-tones, its striking light effects, and its delicate tones of heliotrope and blue. An excellent black-and-white reproduction of this picturesque alchemical interior by Bega adorns the cover of a recent issue of The Laboratory, an interesting advertising periodical published in booklet form by the Fisher Scientific Company of Pittsburg, Pennsylvania.

Some time after the death, in October 1939, of Sir William Pope, his collection was acquired by the Fisher Scientific Company; having survived the perils of an adventurous passage across the Atlantic, it is now safely deposited at Pittsburg in the wellknown Fisher Collection of notable pictures dealing with alchemy and historical chemistry. The Fisher Scientific Company has combined enterprise with good fortune in securing this handsome accession, and the pleasing thought is worthy of expression that the Pope Collection will preserve its identity in the new milieu.

It is a sign of the great interest taken by American chemists, both academic and industrial, in the historical evolution of their science that an American industrial corporation should take such pains in building up a purely historical collection of the kind under notice. While congratulating the United States most cordially on her clear vision and good fortune in this matter, all British chemists who appreciate the interest, inspiration and educative value of historical chemistry will entertain a feeling of regret that a collection of such outstanding merit as that of Pope could not have been preserved in Cambridge.

These beautiful alchemical paintings and engravings, together with the fascinating collections of drug jars and ornamented mortars brought together by the same hand, would have formed an artistic and unique addition to the Fitzwilliam Museum, besides providing a memorial truly characteristic of Sir William Pope, who accomplished more for the Cambridge school of chemistry than any other man.

\section{EXCAVATIONS AT ELMSWELL, EAST YORKSHIRE, I938}

XCAVATIONS on the Roman site at Elmswell,
continued by Philip Corder in 1938 (Hull Mus. Pub.,
No. 207; 1940). In the earlier investigations finds
were both plentiful and remarkable, including thirty-
seven coins ranging from one of the Iceni, coins of the
whole Roman period and a barbarous type resembling
a sceatta, pottery unstratified, but of the whole Roman
period in the north, ending with an extensive col-
lection of late fourth century ware, the earliest
decorated Samian being of the period of Domitian,
and stamped Saxon sherds ; and a large pile of iron
slag, estimated at half a ton in weight, "the product
of direct reduction of fairly pure iron ore", which is
similar chemically and petrographically to other
Romano-British slag. The varied nature of the finds
indicated a long period of occupation, which from other finds in the neighbourhood, evidently extended over an area of some square miles from the Bronze Age until Saxon times.

In 1938 a much wider area was trenched-in all about two acres. Ditches were traced, several areas of cobbling or roughly laid chalk blocks were uncovered and one hut floor was examined in detail No stone-built house of Roman date-the principal objective-was discovered. Three more pits, similar to those already recorded, were excavated, and trenching on the triangular promontory some way from the main site revealed a solitary kiln.

The ditch proved to be shallow and not more than 8-9 ft. across. It must be interpreted as a boundary rather than a defence. Parallel to this, but $108 \mathrm{ft}$. to the east, was a second ditch, which must be considered part of the same system. All signs of occupation- 
huts, floors and pits-lie to the north-east of this system. It is therefore improbable that an undiscovered Roman villa lies westward of the site.

In an otherwise undisturbed area south of the stream, a small kiln was discovered which, from the absence of a stoke-hole pit such as is found in a pottery kiln, is thought to have been an oven for roasting or drying wheat before storage. No part of the superstructure, if any, remains. Sherds found in or near the kiln need not be later than A.D. 120 or thereabouts, and two may be so early as the first century A.D.

Six pits have now been found. Two are double with a central ridge or division separating two hollows. All are relatively large, the largest being $17 \mathrm{ft} .3 \mathrm{in}$. in greatest length, and $9 \mathrm{ft} .4 \mathrm{in}$. in greatest width. Every one had been deliberately filled in by tipping in large quantities of wood-ash and dark soil containing charcoal and potsherds. Three were sealed or partially sealed by humps of clay burnt to bricklike hardness. These may have come from ovens or kilns. All are interpreted as storage pits, but two may possibly have been working hollows. The pottery from the pits is of mixed dating. The earliest indicate a date of first occupation late in the first century A.D., while the absence of Signal Station types show disuse before A.D. 370 .

It is concluded that the site is that of an insignificant Iron Age village inhabited apparently without interruption from about the middle of the first century A.D. until at least A.D. 500. The chief occupation of the inhabitants was the production of corn. A kiln for the drying or parching of corn, working places where it was prepared for storage, pits for its preservation and an exceptionally large number of hand querns for its grinding are ample evidence for this. In addition, there are unmistakable signs of iron working. Lumps of iron slag on analysis and comparison with known Roman iron slags leave no doubt at all that it is a bloomery slag.

Evidence of regular habitation begins in the first century A.D. A fine piece of repoussé bronze work associated with champlevé enamel is to be placed in the third quarter of that century. From the pottery it would appear that the Parisii folk who lived here could afford to supplement their home-made pottery by acquiring Roman utensils almost as soon as these were available in the north after the conquest of the Brigantes and the permanent establishment of the Ninth Legion at York. From that time until the end of the fourth century there is no sign of a break in continuity of occupation as attested by coins or pottery. It is possible that occupation continued uninterrupted into pagan Saxon times. Sherds and small objects may date so late as A.D. 500. Hybrid types have suggested "Romano-British women making pots in the Saxon manner for Saxon masters". It is on such a site as this that one might find the enslavement of a sub-Roman population. Not deeply Romanized, they would change masters without serious dislocation in their way of life.

The panel of Celtic ornament from Elmswell, a remarkable example of Celtic art, which was found in 1938, is described by Philip Corder and discussed by C. F. C. Hawkes (Hull Mus. Pub., No. 209; 1940). As it was unstratified and unassociated, its dating depends entirely on internal evidence. It consists of a thin sheet of bronze covered with an embossed design of flowing curves garnished with rosettes, and fitting on, along its upper edge, to an oblong cast. bronze strip decorated with champlevé enamel of a bright orange-red colour, in large part now discoloured green. Beneath comes an iron plate, now incomplete and corroded, which has been bent along its lower margin to form a flange. In all probability it is a panel which ornamented a wooden box or casket. Its dimensions are: length, 5 in.; breadth, $3 \cdot 1$ in. On technological, stylistic and historical grounds, it is assigned to British workmanship under Belgic-Romanizing influence. This conforms to the state of affairs in the Parisian territory of East Yorkshire in, and perhaps some little time after, the second quarter of the first century A.D. The different arguments concerning the style of the panel are summed up as pointing to a date A.D. 50-70, and most probably about A.D. 60 (see also NAture, 146, $433 ; 1940$ ).

\section{FORTHCOMING EVENTS}

\section{Monday, February 24}

Royal Geographical Society (at Kensington Gore, London, S.W.7), at 5 p.m.-Surgeon-Commander Murray Levick: "The 1938 Expedition to Newfound. land" (Colour Films).

\section{Wednesday, February 26}

Royal Society of Arts (at John Adam Street, Adelphi, London, W.C.2), at 1.45 p.m.-Major C. P. Ackers: "Private Estates and Forestry".

\section{Friday, February 28}

North-East COAST Institunion OF Engineers aND Shipbuidders (in the Mining Institute, Newcastleupon-Tyne), at 6 p.m.-Mr. E. E. Bustard: "Pre. liminary Calculations in Ship Design"

\section{APPOINTMENTS VACANT}

APPLICATIONS are invited for the following appointments on or before the dates mentioned :

SPEECK Therapist to the Yorkshire (West Riding) Education Com. mittee-The Education Officer, County Hall, Wakefleld (February 27)-

Public Analyst to the Soke of Peterborough County Council and the City of Peterborough-The Town Clerk, Town Hall, Peterborough the City of Peterborough-The Town Clerk,

Principal of the Brighton Municipal Training College for WomenThe Education Officer, 54 Old Steine, Brighton (February 28).

Lacturer in Dremetics and Anatomx--The Principal, Battersea Polytechnic, Battersea, London, S.W.11 (February 28).

Assistant Master (Graduate) to take Grneral Engineerive SUBJECTs including ENGINGaring DRAWING AND APPLIED MATHEMaTICS-The Principal, Twickenham Technical College, Egerton Road, Twickenham (March 1).

Assistant DIRECTOR at the Anglo-Uruguayan Institute in Montevideo-The British Council, 3 Hanover Street, London, W.1 (endorsed 'Uruguay') (March 1). GRADUATE (MALE) for the English Room, University of Oporto,
Portugal-The British Council, 3 Hanover Street, London, W.1 (endorsed 'Portugal') (March 1).

DEPCTy ENGINEER to the Essex Rivers Catchment Board-The Clerk to the Essex Rivers Catchment Board, Essex Rivers House, Springfleld Road, Chelmsford (March 3).

HEADMaSter of the Sunderland Junior Technical School--The Director of Education, Education Offices, 15 John Street, Sunderland (March 10).

LECTURER For ENGINEering DRAWING AND OTHER MECHaNical FNaIn St. John Street, London, E.C.1.

LECTURER (MAN OR WOMAN) in the Department of Pure and Applied Science-The Registrar, Loughborough College, Loughborough.

Three Assistant Conservators of Forests-The Controller, Suan Government Londion Office, Oxford Hotel, 261 Clifton Drive Sudan Government London Office, Oxford Hotel, 261 Clifton Drive
South, St. Annes-on-Sea, Lancs. (endorsed 'Conservator of Forests'). 